\title{
Recruiting the underrepresented to academic libraries
}

\author{
By the ACRL Task Force on Recruitment \\ of Underrepresented Minorities
}

Janice Beaudin

Chair, ALA/OLOS Library Service for American Indian People Multicultural Outreach Coordinator University of Wisconsin

\section{Em Claire Knowles}

Assistant Dean

Graduate School of Library and

Information Science

Simmons College

\author{
Edith Maureen Fisher (Chair) \\ President, Black Caucus of ALA \\ Associate Librarian and Ethnic Studies \\ Consultant \\ University of California, San Diego
}

\section{and Ichiko Morita}

President, Asian/Pacific American

Librarians Association

Associate Professor

Head of Cataloging

Ohio State University

\section{The Final Report of the ACRL Task Force spells out challenges and opportunities for minorities.}

$\mathbf{T}$ he Association of College and Research Libraries Task Force on Recruitment of Underrepresented Minorities was established by ACRL President Joseph Boissé, with the approval of the ACRL Board of Directors. Its first meeting was held at the 1989 ALA midwinter conference in Washington, D.C. At that first meeting ACRL President Boissé stated his concern that the ACRL membership needs to resemble more closely the diversified ethnic and cultural population of the United States. This means that greater efforts are imperative to attract underrepresented minority groups (African Americans or Blacks, American
Indians or Native Americans, Asian Americans or Asian and Pacific Islanders, and Hispanic or Spanish-Speaking Americans) to the profession and to academic libraries. The Task Force charge is:

To identify strategies which can be used to recruit to academic librarianship individuals from underrepresented minority groups;

Editor's note: On November 9, 1990, the ACRL Executive Committee took action on this report. Their actions are listed at the end of the article (page 1028). 
To evaluate the potential effectiveness of these strategies;

And to recommend a course of action which the ACRL can pursue during the next decade.

In addition to the Task Force's charge, the ACRL's Strategic Long-Range Plan acknowledges the need to "Support the recruitment of members of underrepresented groups to academic librarianship" (Goal III, Subgoal C, Objective 2).

With the first Task Force meeting in Washington, D.C., a number of academic librarians and others attended each meeting to contribute their ideas and concerns. A lively brainstorming session at the first meeting generated a lengthy list of ideas and strategies for the Task Force to consider.

During the 1989 ALA annual conference in Dallas, those attending the second Task Force meeting discussed ideas for a report and for conference programs. It was agreed that the Task Force would focus on preparing a report and action plan prior to considering program planning.

During the 1990 ALA midwinter conference in Chicago, attendees at the third Task Force meeting commented on and contributed ideas to a "draft" report and assisted the Task Force in developing recommendations. A flyer soliciting academic librarians and others to critique a subsequent "review" version of the report was also distributed. In addition, the flyer was mailed to each attendee of previous Task Force meetings, to other select individuals, and to ethnic organizations in library and information science. A "review" version of the report was sent to each individual who agreed to critique it.

During the 1990 ALA annual conference in Chicago the Task Force has completed its term of appointment and submit a final report to the ACRL Board of Directors. The report acknowledges in its introduction patterns of low recruitment efforts and minimal attention to the advancement and retention of underrepresented groups. To begin reversing these patterns, key targets to challenge are identified as:

1) Institutional commitment to change and accountability. The recruitment, advancement, and retention of underrepresented groups needs to be a high priority and responsibility supported and directed in academic libraries by the leadership of the highest level of administration. There needs to be a commitment to change and accountability for the recruitment advancement and retention of underrepresented groups that goes beyond the rhetoric and reactions to university affirmative action mandates, which notably achieve long-term goals with minimal results.

2) Personal and institutional racism barriers. There is a growing and renewed concern about the impact of racism. It is a barrier individuals and institutions must be sensitive to and must struggle to overcome. Racism is often invisible to all except its victims. Nonvictims often find it difficult to perceive their racism because their racism is by definition the normal practices, customs, and habits of a majority group that tend to disadvantage a minority group. Leadership is needed to eradicate racism barriers and challenge and expose racial insensitivity and unacceptable or unethical actions and practices.

3) Barriers to advancement and retention. Serious attention needs to be focused on eliminating barriers to advancement and retention, cornerstones to recruitment, of underrepresented librarians. "Glass ceilings," "early plateauing," or the "cycle of frustration" where minorities experience difficulties, are denied advancement, and ultimately leave the library are too often becoming the plight of underrepresented librarians. Leadership is needed to eliminate the factors that contribute to this phenomenon.

The report notes the importance of developing objective measures to determine the effectiveness of recruitment strategies in its section on recruitment strategies and evaluation. It then outlines a range of recruitment strategies for the following targets of opportunity:

1) Professionals seeking employment;

2) Paraprofessional library staff and students;

3) Youngsters in grade school.

Among the recruitment strategies outlined are improvements in: 1) position announcements; 2) advertising; 3) soliciting of information on resumes; 4) interview processes; 5) networking; 6 ) skill development training, 7) assessment of entry-level trainee internships; 8) administrative and management apprenticeships, and exchange programs 9) opportunities for career outreach training; 10) career outreach for paraprofessional library staff and for students; 11) regard for the importance of mentoring, role modeling and other support efforts; 12) regard for participation in library school programs, curriculum, and recruitment efforts; 13) efforts by library schools to recruit, and provide financial assistance, mentoring, and curriculum for students from underrepresented groups, and to increase the number of library school administrators and faculty from underrepresented groups; and 14) regard for participation in youth programs to arouse interest in librarianship at an early age in youngsters from underrepresented groups.

The Task Force realizes that its efforts are only an initial step and that there is much work ahead. In the report's last section it recommends a timetable and details for the ACRL Board of Directors to take leadership responsibility and initiate the following actions:

1) Issue position statements on key targets to challenge to reverse patterns of low recruitment and minimal attention to the advancement and 
retention of underrepresented librarians, which are identified as the following: institutional commitment to change and accountability, personal and institutional racism barriers, and barriers to advancement and retention.

2) Appoint a standing Coordinating Committee on the Concerns of Recruitment, Advancement and Retention of Underrepresented Groups in Academic Libraries to ensure continued focused attention to these areas.

3) Establish a Coalition of Underrepresented Academic Librarians to promote new efforts to achieve meaningful communication and exchange of concerns and ideas between these librarians and ACRL.

4) Commission consultants and adivisers to develop initiatives and recommendations for training in academic libraries in the areas of racism awareness; empowerment to counteract racial insensitivity; ethnic and cultural awareness.

5) Conduct a needs assessment and establish guidelines for entry-level trainee internships and other academic library positions for underrepresented librarians.

6) Initiate a national academic library administration and an academic library management apprenticeship for underrepresented librarians to train in these areas. Encourage the initiation of a national library school administration apprenticeship and local academic library administration and management apprenticeships for underrepresented librarians.

7) Sponsor preconference and conference programs to develop and evaluate action plans on concerns of recruitment, and advancement and retention of underrepresented groups in academic libraries.

8) Co-sponsor and participate in the development of programs with local, state, and ALA ethnic organizations, divisions, and units, and library schools that focus attention on issues of recruitment, and advancement and retention of underrepresented groups.

9) Request data from ACRL headquarters, the board, and each committee, section, and chapter on the participation as officers and members of underrepresented librarians and action plans for increasing their participation.

10) Request data from academic libraries on their advancement and retention track record for underrepresented librarians, and their continuing education program activities and plans in the area of race relations.

11) Authorize the Coordinating Committee on the Concerns of Recruitment and Advancement and Retention of Underrepresented Groups in Academic Libraries to initiate and participate in survey and data collection activities to gather relevant information on underrepre- sented librarians in academic libraries, independently and in conjunction with other efforts in survey and data collection. Encourage academic libraries and librarians to contribute to these and other survey and data collection efforts.

12) Authorize the Coordinating Committee on the Concerns of Recruitment, and Advancement and Retention of Underrepresented Groups in Academic Libraries to work with the Association of Research Libraries and other relevant organizations to develop objective measures to determine the effectiveness of efforts of recruitment, and advancement and retention of underrepresented groups.

13) Appoint an Editor to develop an information exchange column in ACRL publications to publicize and highlight programs and activities developed in academic libraries for underrepresented groups.

14) Appoint a Coordinator to initiate a new awareness publicity campaign to attract underrepresented groups to academic libraries, and to connect with, emphasize, and publicize initiatives and efforts already under way.

15) Appoint a panel of judges to administer a series of national academic library awards for underrepresented groups to recognize their outstanding contributions in academic library leadership, research, mentoring, and paraprofessional or student staff services. Encourage academic libraries to model local awards on the national award series.

16) Engage in simultaneous funding activities to improve funding for underrepresented groups in academic libraries.

The report is a collaborative product of those academic librarians and others who have generously contributed their ideas and concerns to the Task Force. Special thanks are extended to each of them. An acknowledgment list follows of those who attended meetings, critiqued the "review" report, and/or requested information. In addition, Jacqueline Gadois (UC, San Diego) is thanked for her administrative assistance, Emily Woolf (Simmons College) is thanked for her editorial assistance, Laura Sheppard (Ohio State Univ., Columbus) is thanked for her volunteer work, and Mary Helen Moreno (UC, Davis) is thanked for her assistance. The Task Force members are also thanked and acknowledged for their contributions and efforts.

\section{Introduction}

Attention to the recruitment and advancement and retention of underrepresented groups in libraries is an idea whose time has come-again! Recruitment of these groups gained widespread national attention in the 1960s and 1970s. Such attention, however, subsequently gave way and was 
ACKNOWLEDGMENTLIST

\begin{tabular}{|c|c|c|}
\hline $\begin{array}{l}\text { Elizabeth R. Ader } \\
\text { Univ. of Missouri, KC }\end{array}$ & $\begin{array}{l}\text { Malcolm C. Hamilton } \\
\text { Harvard Univ. }\end{array}$ & $\begin{array}{l}\text { Margie Simon } \\
\text { Univ. of Maryland }\end{array}$ \\
\hline $\begin{array}{l}\text { Stanton F. Biddle } \\
\text { Brooklyn, NY }\end{array}$ & $\begin{array}{l}\text { Leta Hendricks } \\
\text { Ohio State Univ. }\end{array}$ & $\begin{array}{l}\text { Gloria Smith } \\
\text { Univ. of Arizona }\end{array}$ \\
\hline $\begin{array}{l}\text { Emily Blecher } \\
\text { Princeton Univ. }\end{array}$ & $\begin{array}{l}\text { Barbara B. Higginbotham } \\
\text { CUNY, Brooklyn }\end{array}$ & $\begin{array}{l}\text { William J. Studer } \\
\text { Ohio State Univ. }\end{array}$ \\
\hline $\begin{array}{l}\text { Rhea Bradley } \\
\text { VA Commonwealth Univ. }\end{array}$ & $\begin{array}{l}\text { Mickey Ann Hinojosa } \\
\text { PALINET, Philadelphia }\end{array}$ & $\begin{array}{l}\text { Vivian Sykes } \\
\text { UC, Santa Cruz }\end{array}$ \\
\hline $\begin{array}{l}\text { Diana Brice } \\
\text { Univ. of Colorado, Denver }\end{array}$ & $\begin{array}{l}\text { Susana Hinojosa } \\
\text { UC, Berkeley }\end{array}$ & $\begin{array}{l}\text { Pat Tarin } \\
\text { Univ. of Michigan }\end{array}$ \\
\hline $\begin{array}{l}\text { Janice Burrows } \\
\text { UC, Berkeley }\end{array}$ & $\begin{array}{l}\text { Richard Jasper } \\
\text { Emory Univ. }\end{array}$ & $\begin{array}{l}\text { Joyce G. Taylor } \\
\text { Marion Co. PL, IN }\end{array}$ \\
\hline $\begin{array}{l}\text { Karyle S. Butcher } \\
\text { Oregon State Univ. }\end{array}$ & $\begin{array}{l}\text { Rebecca Johnson } \\
\text { Univ. of Iowa }\end{array}$ & $\begin{array}{l}\text { Clarence Toomer } \\
\text { Durham, NC }\end{array}$ \\
\hline $\begin{array}{l}\text { Meredith Butler } \\
\text { SUNY, Albany }\end{array}$ & $\begin{array}{l}\text { Sharad Karkhanis } \\
\text { Brooklyn, NY }\end{array}$ & $\begin{array}{l}\text { Tamara F. Trujillo } \\
\text { Sacramento, CA }\end{array}$ \\
\hline $\begin{array}{l}\text { Robert Caban } \\
\text { Decatur, GA }\end{array}$ & $\begin{array}{l}\text { Bill Keller } \\
\text { Geo. Washington Univ. }\end{array}$ & $\begin{array}{l}\text { Sally Tseng } \\
\text { UC, Irvine }\end{array}$ \\
\hline $\begin{array}{l}\text { Maidel Cason } \\
\text { Univ. of Delaware }\end{array}$ & $\begin{array}{l}\text { Curtis Kendrick } \\
\text { SUNY, Stony Brook }\end{array}$ & $\begin{array}{l}\text { Patricia Turner } \\
\text { Univ. of Minnesota }\end{array}$ \\
\hline $\begin{array}{l}\text { Rafaela Castro } \\
\text { UC, Davis }\end{array}$ & $\begin{array}{l}\text { Rhonda Rios Kravitz } \\
\text { Calif. State Library }\end{array}$ & $\begin{array}{l}\text { Benita Vassallo } \\
\text { Geo. Washington Univ }\end{array}$ \\
\hline $\begin{array}{l}\text { Clarence Chisholm } \\
\text { Athens, } \mathrm{OH}\end{array}$ & $\begin{array}{l}\text { Catherine A. Larson } \\
\text { Univ. of Iowa }\end{array}$ & $\begin{array}{l}\text { Sandy Vella } \\
\text { UC, Davis }\end{array}$ \\
\hline $\begin{array}{l}\text { Bob Cookingham } \\
\text { Brooklyn College }\end{array}$ & $\begin{array}{l}\text { Laurel Minott } \\
\text { Michigan State Univ. }\end{array}$ & $\begin{array}{l}\text { Maurice B. Wheeler } \\
\text { Detriot, MI }\end{array}$ \\
\hline $\begin{array}{l}\text { Luella Davis } \\
\text { Emory Univ. }\end{array}$ & $\begin{array}{l}\text { Margaret Myers, ALA } \\
\text { Off. Lib. Pers. Res. }\end{array}$ & $\begin{array}{l}\text { Marilyn Wilson } \\
\text { UC, San Diego }\end{array}$ \\
\hline $\begin{array}{l}\text { Alma Dawson } \\
\text { Louisiana State Univ. }\end{array}$ & $\begin{array}{l}\text { Charles R. Peguese } \\
\text { State Lib. of PA }\end{array}$ & $\begin{array}{l}\text { Joyce C. Wright } \\
\text { Univ. of Illinois }\end{array}$ \\
\hline $\begin{array}{l}\text { Barbara Dewey } \\
\text { Univ. of Iowa }\end{array}$ & $\begin{array}{l}\text { Roberta Pitts } \\
\text { Texas A \& M Univ. }\end{array}$ & $\begin{array}{l}\text { Kenneth A. Yamashita } \\
\text { San Joaquin Co. PL }\end{array}$ \\
\hline $\begin{array}{l}\text { Thomas Duszak } \\
\text { St. Library of PA }\end{array}$ & $\begin{array}{l}\text { Barbara Rapoport } \\
\text { UC, Los Angeles }\end{array}$ & $\begin{array}{l}\text { Max Yela } \\
\text { Univ. of Delaware }\end{array}$ \\
\hline $\begin{array}{l}\text { Mary George } \\
\text { Princeton Univ. }\end{array}$ & $\begin{array}{l}\text { Vee Salabiye } \\
\text { UC, Los Angeles }\end{array}$ & $\begin{array}{l}\text { Peter R. Young } \\
\text { Faxon Institute }\end{array}$ \\
\hline $\begin{array}{l}\text { Jan Gilligan } \\
\text { Washington, DC }\end{array}$ & $\begin{array}{l}\text { Lynne Simpson Scott } \\
\text { Emory Univ. }\end{array}$ & $\begin{array}{l}\text { MarieZielinska } \\
\text { Nat'l Library, Ottawa }\end{array}$ \\
\hline
\end{tabular}

replaced by patterns of low recruitment efforts and minimal attention to advancement and retention. To begin reversing these patterns, key targets to challenge are: 1) institutional commitment to change and accountability; 2) personal and institutional racism barriers; 3) barriers to advancement and retention, the cornerstones to recruitment.

Currently there are very real and increasing discussions in higher education on college and university campuses across the nation on: 1) renewed emphasis on undergraduate education, which in many systems means growing percentages of underrepresented students; 2) demands for diversity in the administration and faculty which then also extends to the library; 3 ) demands for classes and materials that adequately reflect the experiences of all American people; 4) the increasing numbers of underrepresented students that demand materials of interest to them and to help them work with their communities; and 5) the renewed emphasis and study of "pipelines" for underrepresented faculty and others, i.e., graduate education and its curriculum. In this current climate, ACRL has a responsibility to provide the 
leadership necessary to take action that can improve the recruitment, advancement and retention of underrepresented groups in academic libraries.

Institutional commitment to change and accountability. Leadership is needed in academic libraries from the highest level of administration for a commitment to change and accountability for the recruitment, and advancement and retention of underrepresented groups that goes beyond the rhetoric and reactions to university affirmative action mandates, which notably achieve long-term goals with minimal results. Once the demands of such legal mandates increase further commitment to change and accountability for these areas contributes to the dilemma of low recruitment efforts and minimal attention to advancement and retention of underrepresented groups.

Recruitment, advancement and retention of underrepresented groups needs to be a high priority and responsibility supported and directed in academic libraries by the leadership of the highest level of administration, to the administrative and management staff level, to the professional staff level, and to other library staff. All library staff needs to be educated about personal and institutional racism, and ethnic and cultural awareness and sensitivity, as well as affirmative action policies and guidelines, and notions of reverse discrimination. Administrators, managers and supervisors need to be accountable for measurable results in improving the recruitment, and advancement and retention of underrepresented groups in their libraries. The ACRL should take the leadership to ensure that academic libraries are committed to change and accountability beyond the rhetoric of affirmative action to improve the recruitment and advancement and retention of underrepresented groups.

Personal and institutional racism. Racism is a barrier individuals and institutions must be sensitive to and must struggle to overcome. Old-fashioned racism and prejudice have evolved to modern racism and prejudice. Negative racial attitudes and prejudice are, for the most part, no longer as clearly exhibited in behaviors as they once were. Racism may be unconscious. Racism can often be expressed in behaviors where there is a plausible, nonprejudiced explanation available for what might be considered prejudiced behavior. An individual may consider his or her behavior nonprejudiced yet the negative net effect can be prejudiced. Often awareness and perceptions of racism differ from the point of view of underrepresented groups and those in the majority. In Ann Knight Randall's chapter on "Minority Recruitment in Librarianship" in Librarians for the New Millennium, edited by W. Moen and K. Heim (Chicago: ALA/OLPR, 1988), she notes it has been argued that "White institutions are inherently racist, but this is invisible to all except the victims. Whites find it difficult to perceive their racism because their racism is by definition the normal practices, customs, and habits of a majority group that tend to disadvantage a minority group.

A significant portion of librarians consider libraries racist working environments. A growing and renewed concern about the impact of racism has led to a number of consciousness-raising conferences and workshops within ALA aimed at heightening racial sensitivity. For example, the 1987 ALA preconference "Librarians As Colleagues: Working Together Across Racial Lines," and the 1988 ALA conference programs "Librarians As Colleagues Across Racial Lines: Strategies for Change" and "White Women Working Together on Personal and Institutional Racism" tackled these issues. These programs are encouraging signs, but they need further support to continue, and they need to be measured for effectiveness. An increasing number of race relations consultants and advisers conduct seminars and workshops to assist library staff in recognizing and handling the issues involved in racism. This growing and renewed concern about racism has also led to such exposé articles as Elizabeth Martinez Smith's "Racism: It Is Always There" (Library Journal, (November 1, 1988) pp. 35-39), and Patrick A. Hall's "Yassuh! I's the Reference Librarian!" (American Libraries, (November 1988) pp. 900901.) The effects of racism are capsulized by Ann Knight Randall in her chapter already cited on "Minority Recruitment in Librarianship."

It is important to begin educational efforts to empower underrepresented librarians and others to challenge racism barriers, racial insensitivity, and unacceptable or unethical actions and practices in libraries. Such efforts should include information about available support, assistance and information to pursue rights and options, and to activate effective intervention to resolve concerns. ACRL should take the leadership in eradicating racism barriers in academic libraries, and in ensuring that underrepresented librarians and others are empowered to effectively challenge and expose racism barriers in academic libraries.

Barriers to advancement and retention. It is time to focus serious attention on advancement and retention, the cornerstones of recruitment. Identifying the barriers to the advancement and retention of underrepresented librarians requires analysis and administrative attention. Underrepresented librarians often experience "glass ceilings," "early plateauing," or the "cycle of frustration" where they experience difficulties, are denied advancement, and ultimately leave the library. Many also often find themselves in marginal, stereotyped, and token positions with no advancement. Library administration and management is often 
frustrated that their past efforts to hire underrepresented librarians prove problematic because they are unable to retain them. The usual result of this "cycle of frustration" is often a renewed effort to recruit new underrepresented librarians. The new recruits enter the library, experience difficulties, are eventually denied advancement, do not realize their potential or their expectations, leave the library, and the cycle begins all over again. Further discussion of this phenomenon appears in "Managing Diversity," Library Personnel News 3, no. 4 (Fall 1989): 60-61.

Successful underrepresented librarians are always excellent role models for new underrepresented librarians. Unsuccessful underrepresented librarians or those experiencing difficulties in their libraries will hardly encourage the recruitment of new underrepresented librarians. It is essential to ensure that underrepresented librarians are being treated fairly and offered opportunities for success and advancement, and are being recognized for their special skills and contributions. Conscientious efforts are necessary to ensure that underrepresented librarians are being treated fairly, and encouraged, supported, and motivated to seek advancement to higher positions and to reach their potential. It is especially important to recognize the very real burdens, stresses and anxieties, professional and personal, that underrepresented librarians often face, especially when they are the lone member or part of a small number of librarians of their group or of underrepresented librarians.

Conscientious efforts are also necessary to ensure that underrepresented librarians' involvement, contributions, and leadership roles in professional organizations, committees, task forces, and other activities focusing on underrepresented groups are neither trivialized or dismissed, but are accordingly regarded, encouraged, and supported as being as significant and as prestigious as participation in other types of organizations. The special skills and contributions of underrepresented librarians to these activities are invaluable and should be recognized for their importance. Often such activities are a primary avenue for underrepresented librarians' professional growth, development, and contribution. ACRL should take the leadership to ensure: 1) that academic libraries eliminate barriers to the advancement and retention of underrepresented librarians; 2) the success of underrepresented librarians in academic libraries; and 3) that activities of underrepresented librarians focusing on underrepresented groups are regarded as prestigious and significant as other types of activities.

The next sections of the report outline a range of recruitment strategies needed for specific targets of opportunity, and recommends a plan of action and timetable for the ACRL Board of Directors.

\section{Recruitment strategies and evaluation}

Simultaneous strategies for recruitment, and advancement and retention of underrepresented groups must be put in place now and permanently. It is important that objective measures be developed to evaluate the effectiveness of strategies to improve the recruitment, and advancement and retention of underrepresented groups. Due to this lack of objective measures no evaluation has been attempted of the potential effectiveness of the recruitment strategies outlined in this section.

Among the range of recruitment strategies outlined in this section are improvements in: 1) position announcements; 2) advertising; 3) soliciting of information on resumes; 4) interview processes, 5) networking; 6) skill development training; 7) assessment of entry-level trainee internships; 8) administrative and management apprenticeships, and exchange programs; 9) opportunities for career outreach training; 10) career outreach for paraprofessional library staff and for students; 11) regard for the importance of mentoring, role modeling and other support efforts; 12) regard for participation in library school programs, curriculum, and recruitment efforts; 13) efforts by library schools to recruit, and provide financial assistance, mentoring, and curriculum for students from underrepresented groups, and to increase the number of library school administrators and faculty from underrepresented groups; and 14) regard for participation in youth programs to arouse interest in librarianship at an early age in youngsters from underrepresented groups. The targets of opportunity for this range of recruitment strategies are:

1) Professionals seeking employment

2) Paraprofessional library staff and students

3) Youngsters in grade schools.

The ALA Office for Library Personnel Resources (OLPR) has a general recruitment network with periodic mailing for individuals interested in new recruitment information and materials. State recruitment networks also exchange information on recruitment efforts.

\section{Professionals}

\section{Position Announcements}

- Emphasis on the potential to contribute to academic libraries and to the campus community needs to appear and be stressed in position descriptions and job announcements.

- Continuing education and training needs to be emphasized and considered equally important as experience.

- Skills need to include demonstrated success in working with underrepresented populations, and ability to effectively communicate across cultures. 
- Duties and responsibilities need to be expressed precisely to apprise prospective candidates of the expectations.

- Restrictive stipulations need to be eliminated, for example, those requiring "previous academic library experience," and specific years or types of experience.

- Any information deemed important to attract underrepresented librarians needs to be included on the position announcement rather than in a separate cover letter.

- Statements other than the overused legal "Equal Opportunity/Affirmative Action Employer" need to be used that can reflect a conscientious commitment to attract and hire underrepresented librarians. For example, a listing might read "We are especially interested in increasing the ethnic and cultural diversity in our professional staff" or "Ethnic and culturally diverse professionals are strongly encouraged to apply."

- Finally, it needs to be recognized that underrepresented librarians are often readily available for employment opportunities in their local area.

\section{Advertising}

- Newsletters, directories, and mailing lists produced by the various ALA, and local and state, ethnic organizations need to be used in addition to conventional advertising sources already in use. The ALA/OLPR produces an annual list of Minorities and Women: A List of Major Organizations in Librarianship which includes their various publications and other information.

- Leaders and members in ALA, and local and state, ethnic organizations need to be identified and contacted to consider and circulate advertisements.

- A statement that reflects a conscientious commitment to attract and hire underrepresented librarians needs to be included when using library telephone joblines and other placement services. The ALA/OLPR produces an annual Guide to Library Placement Sources which lists the various joblines, placement services and specialized agencies.

- Advertising in ethnic professional periodicals and in local ethnic community newspapers needs to be explored to expand efforts to attract underrepresented librarians.

\section{Resumes}

- In an effort to prevent possible discrimination memberships in professional, social, or fraternal organizations which might reveal an applicant's race or ethnicity are often omitted on their resume. A statement in the position announcement that reflects a conscientious commitment to attract and hire underrepresented librarians may serve to begin reversing this practice. Additional efforts may also be needed.

- Skill development training in resume writing can often be needed, and should be made readily available, to ensure that underrepresented librarians present themselves to the greatest advantage.

\section{Interviews}

- Conscientious efforts are necessary to ensure that underrepresented librarians are included in the interviewing pool of prospective candidates.

- Interview panels of a candidate from an underrepresented group need to include library staff of the underrepresented group. Academic libraries need to regard as an important contribution this special ability of these staff. Should the library lack such staff, an invitation needs to be extended to campus staff members from the underrepresented group.

- Opportunities for input on the decision to hire a candidate from an underrepresented group should be given to library and campus staff from the underrepresented group who meet with that candidate.

- Interview panels need to be trained and skilled, and familiar with the campus and the library's affirmative action philosophy, goals, policies, and guidelines.

- If underrepresented librarians are interviewed for a position and not selected, they need to be informed of what they lacked to be a successful candidate. This will enable them to improve where necessary.

- Skill development training in interviewing can often be needed, and should be made readily availabl, to ensure that underrepresented librarians present themselves to the greatest advantage.

\section{Networks}

- Opportunities to work with underrepresented librarians on committees, task forces, and other professional activities, and who are leaders in ALA, and local and state, ethnic organizations need to be used to establish networks. A Directory of Ethnic Professionals in Library and Information Sciences and Related Career Fields, scheduled for publication in 1990, will be an additional source for contacting underrepresented librarians for establishing networks.

- Underrepresented librarians are often used to provide contacts with other underrepresented librarians. It is a fallacy, however, to assume that a cohesive network exists among all underrepresented librarians.

- Campus and community organizations and groups of the underrepresented groups can serve as sources to contact for establishing networks.

- Skill development training in networking can often be needed, and should be made readily available, to assist underrepresented librarians in developing productive networks.

\section{Trainee internships}

- There are any number of entry-level trainee internships in academic libraries for underrepre- 


\section{The Wilson Indexes on}

Magnetic Tape!

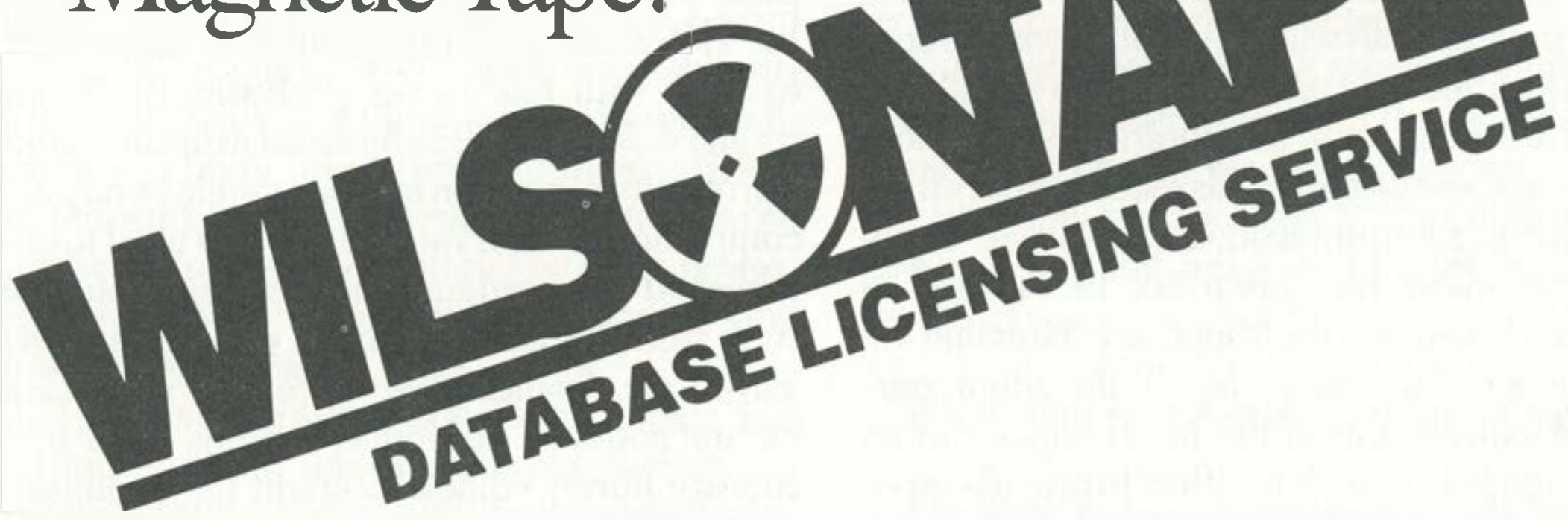

ring the renowned Wilson Indexes to your institution with easy,
unlimited local electronic access. WILSONTAPE provides machine-readable monthly tapes for each Wilson database in a uniform format that makes the data accessible with the same system of commands and protocols as your online catalog.

\section{Create a Customized Databank}

WILSONTAPE:

- Maximizes the use of existing hardware and software and of periodical and book holdings

- Promotes simultaneous use by multiple searchers on a round-the-clock basis

- Supports a uniform set of protocols

- Allows unlimited off-site access to centralized reference holdings

- Saves substantial connecttime charges

- Simplifies billing with a single annual subscription rate.
High-Quality Data in the Format That's Best for Your Library

Setting the standard for accurate, thorough indexing, the Wilson indexes offer access to an extraordinary range of high-quality information unmatched by other indexes, available in the format that's best for your library.

\section{Customized Databanks} at Individualized Rates The Wilson databases are available for licensing at an individualized rate based on two factors: a charge for data and a charge for user access Your initial subscription brings you a full year of retrospective coverage plus monthly updates; all in all, two full years of data.
Integrate WILSONTAPE with Your Library Automation System

Call for details.

\section{Call Toll-Free} 1-800-367-6770

for an individualized price quotation or for more information about WILSONTAPE.

Telefax 1-212-590-1617

\section{T II E H, W. WI I S O I C C II P A R Y Y


sented librarians. They typically last for one to two years, select one or two trainee interns per year, rotate them through various departments and engage them in diverse assignments, and at completion the trainee intern has to seek a permanent position on their own. Potential stumbling blocks associated with these entry-level trainee internships for underrepresented librarians are: 1) participation of professionals in such an entry-level trainee position can be perceived as demeaning and the professionals often perceived as lacking skills; 2) professionals who would otherwise be considered qualified for a permanent academic library position are hired only temporarily; 3 ) the close supervision these professionals receive differs from that of permanent professional employees; 4) potential candidates may often not be inclined to participate because of the temporary status and the limited scope of the internship; 5) the intent, purpose and expectations of the internship are often vague or unclear; 6 ) with no effort to provide exposure of, or to track, these professionals they are relatively unknown for possible permanent positions; 7) these professionals are often not provided with any assistance to ensure they acquire a permanent position in an academic library; 8) there is no opportunity for these professionals to develop a support network among themselves. An additional factor to consider is if these professionals are eventually hired into a permanent position in the same academic library or library system how their prior internship service period is included in salary, advancement, and benefit decisions.

- Upper administrative or middle-management apprenticeships for training underrepresented librarians in these areas are rare and need to be developed.

- Exchange programs to expand the experiences and exposure of underrepresented librarians are nonexistent and need to be developed.

\section{Paraprofessionals and Students}

\section{Career outreach}

- Training needs to be offered for career outreach in attracting paraprofessional library staff and students from underrepresented groups to librarianship. A model, for example, the California Librarians Recruitment Project, held an informational program at a state library conference which included a series of recruitment training workshops; and they produced a handbook describing recruitment techniques and a career information brochure that highlighted various aspects of the information profession, including "Career Opportunities for Minorities in Librarianship" and "Careers in College and University Libraries." (These brochures are available for sale from the California Library Association Main Office, 717 K Street,
Suite 300, Sacramento, CA 95814.) The project's success has been attributed to the partnership of the state's three library schools, combined with the efforts of practitioners from various types of library and information settings, and the representation of underrepresented librarians.

- Paraprofessional staff from underrepresented groups in academic libraries need to be offered career outreach opportunities to attend library school. Important factors contributing to their choosing librarianship as a career can often be: 1) positive work experiences; 2) opportunities to work with role model professionals; 3) mentoring; 4) leave time; 5) financial assistance; and 6) a professional position in an academic library at the completion of library school. Awards need to be established for academic library paraprofessional staff from underrepresented groups to provide leave time, financial assistance, and an academic library position. Academic libraries need to encourage library schools to credit paraprofessional work experience toward required course units.

- Students from underrepresented groups need to be offered career outreach opportunities to interest them in attending library school. They can be contacted through participation with career guidance and admissions office staff in career outreach efforts, and in library orientation sessions, campus and community organizations and clubs, classes, and as library employees. Important factors contributing to their choosing librarianship as a paraprofessional or professional career can often be: 1) positive role models in academic libraries; 2) the opportunity to work in academic libraries; 3 ) mentoring; and 4) financial assistance. Tuition waivers are possible types of financial assistance academic libraries might offer. Examples include, an academic library fellowship consisting of a tuition scholarship, a graduate assistantship position in library school, and a position in an academic library after completing library school; or an academic library internship consisting of tuition reimbursement for library related courses, leave time to attend courses, and a paraprofessional salary as benefits of academic library employment.

- Academic libraries need a designated recruiter(s) for underrepresented groups, an individual(s) or committee responsible for focusing on attracting underrepresented librarians to the academic library, and paraprofessionals and students from underrepresented groups to attend library school.

- Academic libraries and library schools need to regard as significant contributions mentoring, role modeling, and other support efforts offered in career outreach to paraprofessionals and students from underrepresented groups. Such efforts can be critical in ensuring these individuals' success and fostering positive attitudes about library school and 
the information profession. As role models underrepresented librarians and administrators, faculty, and students in library schools from underrepresented groups need to be visible in all aspects of academic library and library school programs and activities.

- The REFORMA/UCLA Mentor Program is a model effort by a library school and a professional organization to provide mentoring, role models, and support by a group of underrepresented librarians for a group of underrepresented students in library school. Academic libraries need to regard mentoring as a significant contribution and encourage the participation of their underrepresented librarians in library school programs and curriculum. Students from underrepresented groups can be attracted to academic libraries by those professionals who have a personal commitment and knowledge base to assist them.

- Academic libraries need to encourage and contribute to library schools increasing the number of administrators and faculty from underrepresented groups by supporting their underrepresented librarians in continuing their education to advance to such positions.

- Academic libraries, in conjunction with library schools, can offer guides to available sources of financial assistance for underrepresented groups produced by individual library schools to aid in their recruitment and admissions efforts. In addition, the ALA Standing Committee on Library Education publishes an annual directory of Financial Assistance for Library Education which lists scholarships and assistantships from a variety of sources, as well as aid for doctoral programs and continuing education for staff. Included is an index of aid specifically targeted to underrepresented groups.

- Guidance, in addition to providing information about funding sources, can often be needed, and should be made readily available, for paraprofessionals and students from underrepresented groups applying for financial assistance.

\section{Youngsters}

\section{Early impressions}

- Academic librarians need to participate with colleagues from school and public libraries in youth programs to arouse interest in youngsters from underrepresented groups about librarianship. For example, the Teenage Library Association of Texas (TALA) provides extracurricular activities for youngsters in high school and middle school which involves them in local library activities. Every other year TALA gives two $\$ 1,000$ scholarships to former members of the group attending library school.

- Academic librarians need to participate in career talks to youngsters from underrepresented groups. For example, the Special Libraries Association's Affirmative Action Subcommittee held discussions with school principals to have teams invited into individual schools to give talks about librarianship. The Recruitment and Professional Development Committee of the Black Caucus of ALA has set goals to develop a contact list of Black librarians interested in going to high schools to discuss their professional careers, and the ALA OLPR has proposed a project to develop a directory of librarian contacts at the local level for recruits from underrepresented groups.

The next section of the report recommends a plan of action and timetable for the ACRL Board of Directors to provide leadership to ensure continuing attention and focus on the recruitment, and advancement and retention of underrepresented groups in academic libraries.

\section{Recommendations: A plan of action}

The Task Force recommends the ACRL Board of Directors endorse and distribute this report, Recruiting the Underrepresented to Academic Libraries: Challenges and Opportunities, and that it adopts the following timetable and plan of action for 1) position statements; 2) committee and coalition appointments; 3) training; 4) programs; 5) survey and data collection; 6) publicity; 7) awards; and 8) funding.

\section{Position statements}

By the 1991 midwinter conference:

1.1. Issue a position statement that recognizes a continuing commitment to change and accountability for the recruitment, and advancement and retention of underrepresented groups needs to be a high priority and responsibility supported and directed in academic libraries by the leadership of the highest level of administration, to the administrative and management staff level, to the professional staff level, and to other library staff.

1.2. Issue a position statement that recognizes racism is a barrier individuals and institutions must be sensitive to and must struggle to overcome; a growing and renewed concern about personal and institutional racism; the need to eradicate racism barriers in academic libraries; the need to empower underrepresented librarians and others to challenge and expose racism barriers in academic libraries; and that encourages national, state, and local consciousness-raising efforts to heighten racial sensitivity in academic libraries.

1.3. Issue a position statement that recognizes the need for academic libraries to focus serious attention on eliminating barriers to the advancement and retention, cornerstones to recruitment, of underrepresented librarians. 


\section{Committee and coalition}

2.1. Appoint a standing Coordinating Committee on the Concerns of Recruitment, and Advancement and Retention of Underrepresented Groups in Academic Libraries to ensure continued focused attention to these individual areas. Appoint a Chair and members by the 1991 midwinter conference. A report and recommendations would be issued beginning at the 1992 national conference and thereafter at every annual and national conference.

Among the expectations for the committee would be to: 1) coordinate activities with other ALA/ACRL efforts; 2) review and assess the procedures and policies of ALA/ACRL in these areas, and develop an ACRL policy document in these areas; 3 ) review relevant literature in these areas to prepare policy recommendations, including the Task Force Final Report, Recruiting the Underrepresented to Academic Libraries: Challenges and Opportunities, the Association of Research Libraries (ARL) Spec Kit \#67 on Affirmative Action, "Academic Libraries and the NCLIS Report of the Task Force on Library and Information Services to Ethnic Minorities" in the major ALA policy document relating to minority concerns Equity At Issue: Library Services to the Nation's Four Major Ethnic Groups, 1985-1986 (ALA Council Document \#30, 1985-1986), and Minorities on Campus: A Handbookfor Enhancing Diversity, edited by Madeleine F. Green (Washington, D.C.: Amererican Council on Education, 1989); 4) engage in statistical and other data collection in these areas; 5 ) review and monitor implementation plans of action in these areas; 6 ) evaluate funding sources and their distribution to support underrepresented groups; 7) monitor, evaluate and issue a list of programs and activities in these areas; 8) examine for their appropriateness and issue a list of ethnic professional periodicals and other sources for advertising; 9) issue a bibliography of articles and publications in these areas.

2.2. Establish a Coalition of Academic Librarians from Underrepresented Groups to promote new efforts to achieve meaningful communication and exchange of concerns and ideas between these librarians and ACRL committees, sections, and chapters. Schedule the first meeting of the Coalition by the 1991 midwinter conference.

\section{Training}

3.1. Commission race relations consultants and advisers to develop initiatives and recommendations for training in academic libraries to deal with personal and institutional racism, and to empower underrepresented librarians and others in academic libraries to counteract racial insensitivity. The initiatives and recommendations would be submitted to the Coordinating Committee on Concerns (2.1.) for review and presentation to the
ACRL Board of Directors at the 1992 midwinter conference.

3.2. Commission multicultural awareness consultants and advisers to develop initiatives and recommendations on ethnic and cultural awareness and sensitivity in academic libraries. The initiatives and recommendations would be submitted to the Coordinating Committee on Concerns (2.1.) for review and presentation to the ACRL Board of Directors at the 1992 midwinter conference.

3.3. Conduct a needs assessment and establish guidelines for entry-level trainee internships and other positions for underrepresented librarians. Determine existing funding levels for these positions. The results would be submitted to the Coordinating Committee on Concerns (2.1.) for review and presentation in 1992 at the midwinter meeting.

3.4. Initiate national apprenticeships for underrepresented librarians in academic library administration and in academic library management, to provide training at the highest level of administration and at the mid or lower level of management in academic libraries. Appoint a planning committee by the 1991 midwinter conference to formulate criteria and procedures for the national apprenticeships. The plans and procedures would be submitted to the Committee on Concerns (2.1.) for review and presentation to the ACRL Board of Directors. Announce the apprenticeships at the 1992 national conference. Encourage academic libraries to initiate local apprenticeships in library administration and in management for underrepresented librarians. Encourage library schools to initiate a library school administration apprenticeship to provide training for underrepresented librarians.

\section{Programs}

4.1. Sponsor preconference programs, in conjunction with the 1992 and 1995 national conferences, to develop and evaluate action plans on concerns of recruitment, and advancement and retention of underrepresented groups in academic libraries. Appoint preconference program planning committees by the 1991 and 1992 midwinter conferences.

4.2. Plan conference programs at the 1993 and 1996 annual conferences to follow the preconferences to highlight concerns and action plans. Appoint a program planning committee by the 1991 and 1993 annual conferences.

4.3. Co-sponsor and participate in the development of programs with local, state and ALA ethnic organizations, divisions, units, and library schools that focus attention on issues of recruitment, and advancement and retention of underrepresented groups. Publicize those programs in the information exchange column of ACRL publications devoted to underrepresented groups in academic libraries (6.1.). 


\section{Surveys and data collection}

Encourage academic libraries and librarians to contribute to efforts to obtain data and information on underrepresented groups.

5.1. Request data from ACRL headquarters, the board, and each committee, section, and chapter on the participation as officers and members of underrepresented librarians, and action plans for increasing their participation. The results and action plans would be submitted to the Coordinating Committee on Concerns (2.1.) for presentation and approval by the ACRL Board of Directors beginning in 1991 at each midwinter conference.

5.2. Request data from academic libraries on their advancement and retention track record for underrepresented librarians, and their continuing education programs and activities (workshops, seminars, etc.) in the area of race relations. The results would be submitted to the Coordinating Committee on Concerns (2.1.) for review and presentation to the ACRL Board of Directors beginning in 1992 at each midwinter conference.

5.3. Authorize the Coordinating Committee on Concerns (2.1.) to initiate and participate in survey and data collection activities to gather relevant information on underrepresented librarians in academic libraries, independently and in conjunction with other efforts in survey and data collection-for example, to review and advise ALA OLPR on the collection of personnel data on underrepresented librarians in academic libraries appearing in Academic and Public Librarians: Data By Race, Ethnicity and Sex; to review and advise on the collection of library education data on recruitment policies, and on curriculum relevant courses dealing with issues on underrepresented groups and with academic libraries; to provide profile information data on underrepresented librarians' career paths and track records for advancement and retention; and on the relationship between the size of the academic library staff from underrepresented groups and its impact on accreditation, as compared with salary levels and size and depth of collections. The Coordinating Committee on Concerns would include such information data in the report submitted to the ACRL Board of Directors (2.1.).

5.4. Authorize the Coordinating Committee on Concerns (2.1.) to work with the Association of Research Libraries and other relevant organizations to develop objective measures to determine the effectiveness of efforts to reach the goals of increasing the number of underrepresented librarians; giving greater recognition to the special skills and contributions of underrepresented librarians; developing a larger percentage of underrepresented librarians that are administrators and managers in academic libraries; increasing the numbers of underrepresented librarians partici- pating in library school and youth programs. The Coordinating Committee on Concerns would include such information in the report submitted to the ACRL Board of Directors (2.1.).

5.5. Authorize the Coordinating Committee on Concerns (2.1.) to conduct a needs assessment and investigate the feasibility of establishing exchange program training for underrepresented librarians in academic libraries. The Coordinating Committee on Concerns would include this in the report submitted to the ACRL Board of Directors (2.1.).

\section{Publicity}

6.1. Appoint an editor by the 1991 midwinter conference to develop an information exchange column in ACRL publications to publicize and highlight programs and activities developed in academic libraries for underrepresented groups, and ACRL programs and activities on underrepresented groups in academic libraries; and to serve as a clearinghouse to exchange other information, i.e., funding sources, new publications, etc., the editor would also consider preparing an annual summary article for the ALA Yearbook. The column should begin to appear in ACRL publications by the 1991 annual conference.

6.2. Appoint a Coordinator by the 1991 midwinter conference to create a new awareness publicity campaign for underrepresented groups to arouse interest in career paths in academic librarianship. The focus of the campaign would be on ensuring the production of posters, brochures, media, etc. highlighting underrepresented librarians in a variety of types of academic library positions. The campaign would not duplicate efforts and would connect with, emphasize, and publicize initiatives and efforts already under way. Materials produced would be distributed to professional organizations, library schools, colleges, and grade schools. The campaign should be launched by the 1991 annual conference.

\section{Awards}

7.1. Appoint a panel of judges by the 1991 midwinter conference to plan, establish criteria, and recommend funding for a series of national academic library awards for underrepresented groups; and to encourage academic libraries to model local awards for underrepresented groups on the national award series. The plan would be submitted to the Coordinating Committee on Concerns (2.1.) for review and presentation to the ACRL Board of Directors at the 1991 annual conference. To be considered among the series would be: 1) academic library leadership award to recognize an outstanding contribution by an academic library or librarian in the leadership of programs or activities for underrepresented groups in academic libraries; 2) academic library research award to encourage and support research investigating race relations in academic libraries in an endeavor to 
have an impact on the development of strategies to eradicate racism in the profession; 3) outstanding mentor award to recognize the librarian, library or library organization developing and contributing to model mentoring activities and projects; 4) academic library paraprofessional or student staff service award to recognize service and professional potential.

\section{Funding}

8.1. Participate with the ALA Washington Office and others to remain vigilant about major funding legislation for library school education, to lobby for improved salaries and status for librarians, and to lobby for a loan forgiveness program for library school students who would work for a certain number of years in an academic library at the completion of library school.

8.2. Initiate and support new or alternative sources of funding to attract underrepresented groups to academic librarianship; to support the continuing education and advancement of underrepresented librarians in academic libraries; and to support the continuing education plans and activities (workshops, seminars, etc.) in academic libraries dealing with race relations. Publicize funding sources in the information exchange column of ACRL publications devoted to underrepresented groups in academic libraries (6.1.).

8.3. Establish funding partnerships with business and industry, the Coalition of Academic Librarians from Underrepresented Groups (2.2.), and others to support awards and other funding assistance for underrepresented groups in academic libraries.

8.4. Identify available sources of funding for underrepresented groups that are not allocated to them and propose solutions to ensure proper allocation.

\section{ACRL acts on minority recruitment report}

The ACRL Executive Committee met on November 9-10, 1990, and took action on the final report from the ACRL Task Force on Recruitment of Underrepresented Minorities (see page 1016-28). The Executive Committee voted to establish an ACRL Standing Committee on Racial and Ethnic Diversity with the following charge: "To initiate, advise, and mobilize support for appropriate action related to issues of racial and ethnic diversity in academic librarianship including the recruitment, advancement and retention of underrepresented groups to academic librarianship; and the promotion of quality academic library and information services for members of racial and ethnic groups." Ford will make appointments to the committee immediately so they will be able to meet at Midwinter. Ford stated that the new committee will be asked to establish priorities and prepare a budget request for the actions identified in the task force report.

The Executive Committee also voted to endorse the position statements included in the task force report. The position statements affirm ACRL's continuing commitment to the elimination of barriers to the recruitment and retention of underrepresented groups.

Ford stated that the task force report will be sent to all ACRL units with a request for consideration and action. Ford stated, "We hope all ACRL com-

\section{Attention serials librarians}

The $C \mho R L$ News annual index for 1990 will appear in the January 1991 issue. mittees, sections, chapters and discussion groups will focus their energies on issues of racial, ethnic and cultural diversity."

\section{Minority recruitment video}

The School of Library and Information Science, University of Pittsburgh, has produced a video, "Librarians for the Information Age," to use in the recruitment of minorities to the profession. The video is narrated by actor Ossie Davis. J.E. Josey, professor at the library school, stated that proceeds from the sale of tapes will be used for financial aid for minority students. He added, "When we were preparing the video, it was our hope that it would parallel and supplement the ALA video, 'The Future Is Information,' and now that we have finished the project, we believe that it does."

Copies of the 10-minute and 47-second video are available for $\$ 35$ from the Department of Library Science, School of Library and Information Science, University of Pittsburgh, 135 N. Bellefield, Pittsburgh, PA 15260. Checks should be made to the University of Pittsburgh.

Copies of the 18-minute ALA video, "The Future Is Information," are available for $\$ 45$ from ALA Graphics, (800) 545-2433 x5046. The 1989 video is available in VHS, Beta or $3 / 4$ U-Matic. 


\section{Cultural diversity in California}

"UCI Library Ethnic Heritage Map" was one of three exhibits staged by the Cultural Diversity Environment Committee at the University of California, Irvine during the Rainbow Festival in November. The map graphically represented the diverse range of countries and cultures in the ethnic backgrounds of UCI Library staff and students. A second exhibit in the Main Library contained ethnic studies materials from the Libraries' collections, while an exhibit in the Library Study Center focused on the movement in the University of California system and throughout academia to broaden the traditional curriculum to include greater representation of the contributions of minorities and women.

All nine campuses of the University of California were represented when librarians met at UCLA for a day-long workshop on cultural diversity in the UC libraries. During the morning session, participants concentrated on the issue paper, "Recruitment and Advancement of Racial and Ethnic Librarians," suggesting means by which more people of color can be hired as librarians into the University of California system. Some suggestions were: encouraging ethnic staff members to attend library school, expanding the existing mentorship program to emphasize minorities, and establishing a permanent systemwide committee to deal with issues of cultural diversity in the university libraries. After lunch, the participants broke up into small groups to discuss the issue papers "Bibliographic Access to Ethnic Collections within the University of California," "Reference Services," "Bibliographic Instruction for Resources on Cultural Diversity in UC Libraries," and "Collection Development for Culturally Diverse Materials in UC Libraries."

\section{Part-timers sought for study}

Part-time librarians: what do you do in your "spare time"? Do you work an additional job?

Elizabeth Medeiros Hogue and Lorene Sisson are involved in a research project studying part-time librarians and their work. They are interested in part-time librarians who work another job, whatever it may be. Please send your name, address, phone number, title of librarian position, and institution name. Please include a brief description of your other job. For information contact: Elizabeth Medeiros Hogue and Lorene Sisson, Clark Library, San Jose State University, San Jose, CA 95192-0028.

\section{National Library Bibliothèque nationale of Canada du Canada \\ Canadiana Products from the National Library of Canada}

The National Library is responsible for promoting, gathering and preserving the published heritage of Canada. The Library has a vast collection of Canadiana dating from Canada's earliest days to the present. In order to provide access to Canada's published heritage the Library has developed various products which are invaluable to those with an interest in Canadian Studies or research.

The Library produces Canadiana, a comprehensive bibliography which documents the nation's published heritage. Canadiana is a valuable aid for Canadian Studies and is available in printed and microfiche formats and on magnetic tape.

- Canadiana authorities lists verified name headings of Canadian origin and can help in compiling bibliographies and answering research and reference questions.

- Canadian Theses is a microfiche bibliography of masters' and doctoral theses accepted by Canadian universities, as well as selected foreign theses of Canadian authorship or interest.

- DOBIS is a Canadian online library system that provides access to the collections of many Canadian libraries via its continuously updated Canadian Union Catalogue of more than 5000000 bibliographic records.

For more information or a descriptive brochure on these products please contact:

National Library of Canada

395 Wellington Street

Ottawa, Canada

KIA ON4

\section{Canadầ}

